\title{
Ex situ and in situ conservation gap analysis of crop wild relative diversity in the Fertile Crescent of the Middle East
}

\author{
Wathek Zair (1) · Nigel Maxted · Joana Magos Brehm • Ahmed Amri
}

Received: 17 October 2019/Accepted: 15 September 2020/Published online: 4 October 2020

(C) The Author(s) 2020

\begin{abstract}
Crop wild relatives (CWRs) are important reservoirs of adaptive traits for crop breeding programmes. Both ex situ and in situ conservation approaches should be deployed to ensure CWR availability for use. This paper aims to (a) create a regional database of occurrence records for the 441 priority CWRs in the Fertile Crescent, (b) identify CWR-rich areas in the Fertile Crescent, (c) recommend locations to implement genetic reserves intended for CWRs active in situ conservation and (d) undertake ex situ and in situ conservation gap analyses. The study area comprises Jordan, Syria, Palestine/Israel, Lebanon, Turkey and Iraq. Occurrence records of the 441 priority CWR within the Fertile Crescent were gathered from herbaria, gene banks and online databases. Gaps in the current ex situ and in situ conservation were identified. Hotspots of CWR diversity were identified, and complementary analysis was carried
\end{abstract}

Electronic supplementary material The online version of this article (https://doi.org/10.1007/s10722-020-01017-z) contains supplementary material, which is available to authorized users.

W. Zair $(\bowtie) \cdot$ N. Maxted · J. M. Brehm

School of Biosciences, University of Birmingham,

Birmingham, UK

e-mail:wathekzair@yahoo.com

\section{A. Amri}

Genetic Resources Section, International Centre for Agricultural Research, Dry Areas (ICARDA), Rabat, Morocco out to identify areas for in situ conservation using DIVA-GIS. Then proposed genetic reserves were compared with the existing protected areas to establish genetic reserve areas whether within or outside the protected areas. A total of 23,878 occurrence records were collated for $441 \mathrm{CWR}$ priorities. The first priority grid square is located in Syria near Tal Kalakh City, close to the Lebanese border from the north. The second priority site is located in Turkey's Izmir Province near Kemal Atatürk Mahallesi. The third priority site is located in Turkey's Sahinbey/Gaziantep Province. The ex situ gap analysis revealed that of the 441 taxa, 134 (30\%) CWRs are totally absent from the current gene banks collections. Only 307 (70\%) CWRs are represented in gene banks, and, of these taxa, $252(57 \%)$ of them have less than 10 accessions in gene banks. A total of 353 taxa were categorised as a high priority for collection and conservation; 23 taxa were categorised as a medium priority and 41 taxa as a low priority. However, 24 taxa were identified that did not require urgent collection (see Supplementary Table 7). The most important areas for a further collection of ex situ conservation are located in the west and south of Turkey across the Mediterranean seashore, north of Lebanon and west of Syria (in Lattakia and Tartus Governorate), across the border between Turkey and Syria and northern Iraq. Ten genetic reserves are recommended in the Fertile Crescent for CWR conservation. The results and methods used will help meet the conservation targets 
of CWR in the Fertile Crescent; they will also help achieve global food security.

Keywords Conservation - Gap analysis - Species richness · Complementary analysis · Genetic diversity

\section{Introduction}

The Fertile Crescent is a geographical term that has been used historically to describe the northern part of the Middle East and the eastern coast of the Mediterranean Sea, including Jordan, Syria, Palestine/Israel, Lebanon, Turkey and Iraq (Breasted 1916; Clay 1924). Not only is the Fertile Crescent recognised for plant species concentration but also specifically for its agrobiodiversity wealth (Vavilov 1926; Zhukovsky 1950; Harlan 1951; Harlan and Zohary 1966; Zohary 1969) in terms of both rich diversity of cultivated plants and wild relatives. It is the domestication centre of major crops, such as Triticum monococcum L. (einkorn wheat), Triticum durum Desf. (durum wheat), Triticum turgidum L. (poulard wheat), Triticum aestivum L. (bread wheat), Hordeum vulgare L. (cultivated tworowed barley), Secale cereale L. (rye), Avena byzantina K. Koch (red oat), Cicer arietinum L. (chickpea), Lens esculenta Moench. (lentil), Pisum sativum L. (pea), Medicago sativa L. (blue alfalfa) and Sesamum indicum L. (sesame) (Hawkes 1983; Morrell and Clegg 2007). The Fertile Crescent region has significant historical value as a place where agriculture was first developed. Recent evidence indicates that agriculture started on a small scale in Ohalo II in Israel around 23,000 years ago (Snir et al. 2015). The Fertile Crescent is a center of plant diversity. It is part of the global hotspot "the Mediterranean Basin". The Mediterranean Basin is a biologically diverse hotspot of global importance, primarily because of its great plant diversity. Approximately $10 \%$ of the Earth's vascular plants $(25,000)$ exist in the Mediterranean Basin on less than $2 \%$ of the area of land on Earth, and 50\% of these species exist nowhere else on the planet (Myers 1990).

To conserve agriculture biodiversity or plant genetic materials, two approaches have been proposed. The first one is in situ conservation, which refers to the conservation of plant genetic materials in their original geographic location in which they belong and their distinctive property that has developed over the years (CBD 1992). In situ conservation can be done in protected areas. A protected area is a geographical area that is built to archive one particular conservation aim or more (CBD 1992). Ex situ conservation is the method that involves conserving species outside their natural surroundings. It could be done in gene banks, botanic gardens or another environment. Crop wild relatives are threatened in their natural habitat; this is due to urbanisation, constructing of roads, deforestation, desertification, intensive farming, erosion of soil and plant genetic resources, pollution of land and water, scarcity of water, overgrazing, and the impact of climate change (El-Beltagy 2006; Derneg 2010). Trigo et al. (2010) state that climate change impacted negatively on the vegetation in the Fertile Crescent (Trigo et al. 2010). For all the above-mentioned reasons, there is an urgent need to conserve CWR in the Fertile Crescent and conserve their natural habitats.

The demand for agrobiodiversity is increasing to help produce more food to feed a growing human population, which is expected to reach 11.2 billion by 2100 (UN 2017); there is also rising expectations among consumers for high-quality crops. The lack of natural resources (e.g. water and farming land), climate change, and land and water pollution have put further pressure on food and agricultural production globally (FAO 2011; Asseng et al. 2015). Although agricultural demand can be somewhat met by reducing food wastage (Tilman and Clark 2014), increased and sustainable agricultural production continues to be needed (Godfray et al. 2010). To achieve global food security, $90 \%$ of the increase in food production will have to come from intensive agriculture and increased crop yield (FAO 2009). One of the major contributions to increased agricultural production involves improving crop varieties using novel genes donated from CWRs, which can be achieved not only by improving yields but also by improving tolerance for different climatic conditions as well as resistance to pests and diseases (Maxted et al. 2000; Araus et al. 2008).

CWRs are wild plants closely related to crops; therefore, they are important sources of novel traits (Maxted et al. 2006) because they have the greatest breadth of adaptive trait diversity as they have not passed through the domestication bottleneck (Tanksley and McCouch 1997). One additional factor in achieving food security involves in situ and ex situ 
conservation as well as using CWRs in crop breeding programmes (Maxted et al. 1997; Zhang et al. 2017). The need to increase food production in the face of climate change necessitates an increased use of CWR diversity to provide the required trait diversity (Maxted et al. 2012; FAO 2015), especially in the context of the Fertile Crescent where increasing drought has been attributed to climate change (Kelley et al. 2015). Vincent et al. (2013) and CastanedaAlvarez et al. (2016) have confirmed that this region is the global centre of CWR concentration with 84 global priority taxa per $25 \mathrm{~km}^{2}$; therefore, conserving the region's CWR diversity is vital to global, as well as regional and local, food security.

Castaneda-Alvarez et al.'s (2016) assessments revealed that a third of CWRs have no accessions and that $72 \%$ of them take a high priority for collection. Furthermore, urbanisation, climate change, and land and water pollution threaten the natural habitats of CWRs (Jarvis et al. 2008). Using the Red List threat assessment methodology of the International Union for Conservation of Nature (IUCN), Kell et al. (2012) discovered that $16 \%$ of European CWRs are in danger of extinction. In the Fertile Crescent, CWRs are specifically threatened by the construction of buildings, expansion of infrastructures, overgrazing and climate change (El-Beltagy 2006; Derneg 2010; Trigo et al. 2010).

Gap analysis is now routinely used as a tool for agrobiodiversity conservation planning (Maxted et al. 2013). It involves finding gaps in existing conservation actions and identifying the under-represented elements, and, therefore, helping to prioritise additional actions (Scott et al. 1991). In the CWR context, gap analysis involves comparing the range of natural diversity with the diversity already conserved ex situ in gene banks or in situ in genetic reserves, with the gaps becoming the recommended additional conservation actions (Magos Brehm et al. 2017).

To facilitate the conservation of CWRs, this study aims to conduct a gap analysis of 441 priority CWRs related to 61 crops. 441 priority CWRs were selected for their social economic value as well as they are endemic. Priority were given to taxa with restricted range and threatened species. This study also intends to recommend more effective conservation methods of CWRs' gene pools to enable farmers and breeders to benefit from their genetic materials.

\section{Methods}

Occurrence records were collated from herbaria, gene banks and online databases for the priority list of 441 CWR taxa in the Fertile Crescent (Zair et al. 2017). The list of data sources of the occurrence records used in the potential distribution modelling and the gap analysis are summarised in Supplementary Table 12. Although the arc of the Fertile Crescent includes only parts of Iraq, Palestine/Israel, Jordan, Lebanon, Syria and Turkey, the conservation gap analysis was conducted for all these countries. Where records had no geographic coordinates but only specific locations, GEOLocate (2017) software was used to obtain latitudes and longitudes. Occurrence data were subsequently verified, and those that occurred outside the boundaries of the Fertile Crescent or were found in the sea were either corrected or deleted (Scheldeman and van Zonneveld 2010).

DIVA-GIS Version 7.5 was then used to plot the occurrence records to produce a distribution map of the priority CWR in the Fertile Crescent (Fig. 1). A species richness map was also produced using 'Point to Grid' and 'Richness' tool in DIVA-GIS Version 7.5 with a grid cell of $0.2^{\circ}\left(\sim 22.2 \mathrm{~km}^{2}\right)$ (Scheldeman and van Zonneveld 2010). DIVA-GIS Version 7.5 was also used to plot CWR observation richness with a grid cell of five minutes $\left(\sim 9 \mathrm{~km}^{2}\right)$. Subsequently, a cell size of $0.2^{\circ}$ and Rebelo et al.'s (1994) algorithm were used to conduct a complementary analysis using the 'Point to Grid' and 'Reserve Selection' functions in DIVA-GIS Version 7.5.

Figure 2 demonstrates the observation richness of CWR priority taxa. The map indicates the north-west of Syria and northern Lebanon as regions with the highest concentration of CWRs. Figure 3 shows the complementary analysis of priority CWR sites and the existing protected areas in the Fertile Crescent. The proposed in situ reserve locations were compared with the existing locations of the protected areas. The existing layers of the protected areas were taken from the Protected Planet (2018) database.

An analysis to cover two-thirds of the CWR taxa was undertaken. The top two-thirds of the total CWR priority taxa comprise 294 taxa $(441 \times 2 / 3=294)$. The CWR taxa for each site were added until reaching 294 or more. 


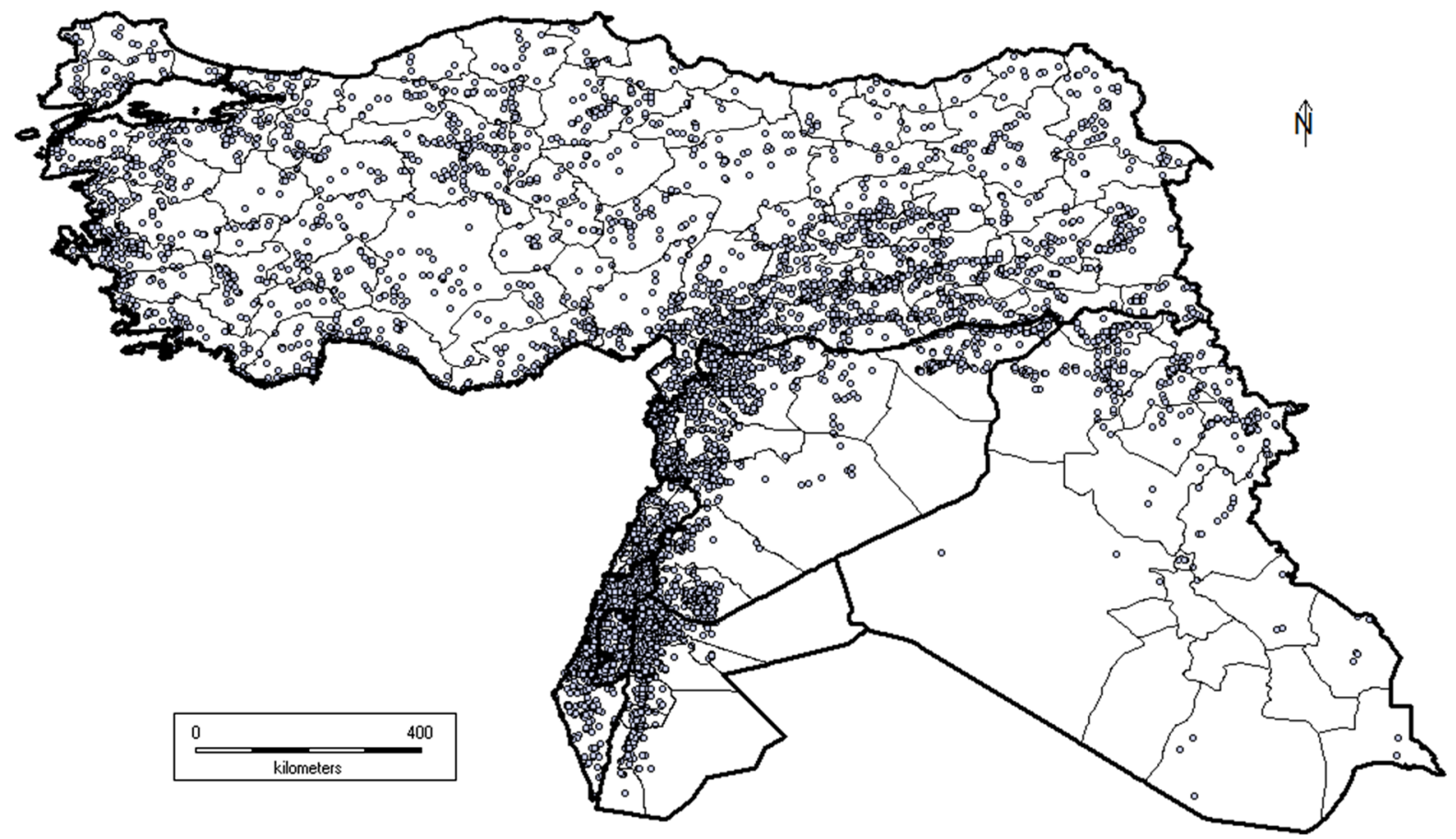

Fig. 1 Presence points of the 441 priority CWR of the Fertile Crescent

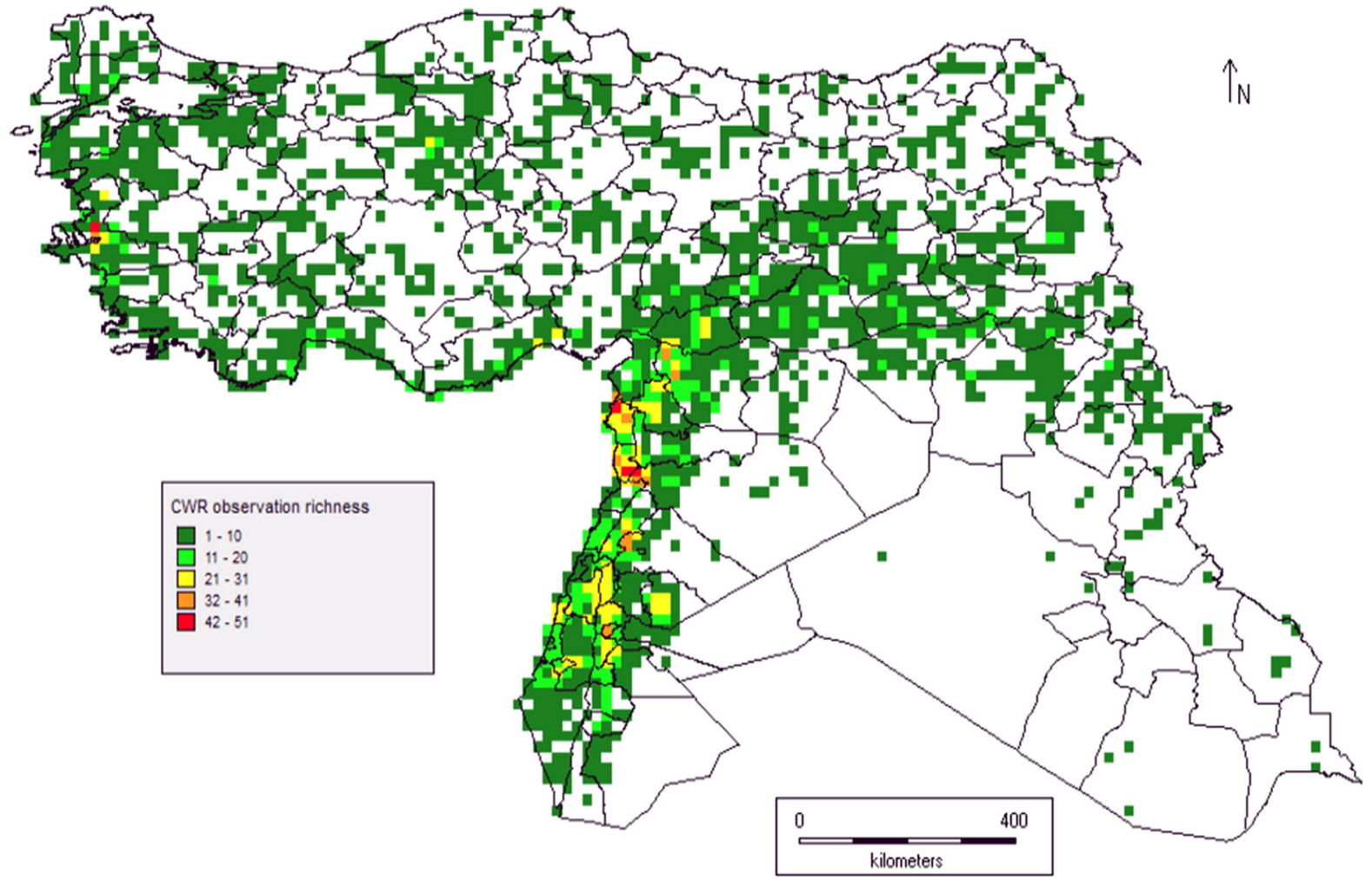

Fig. 2 CWR observation richness with a grid cell of 5-min degrees $\left(\sim 9 \mathrm{~km}^{2}\right)$ 


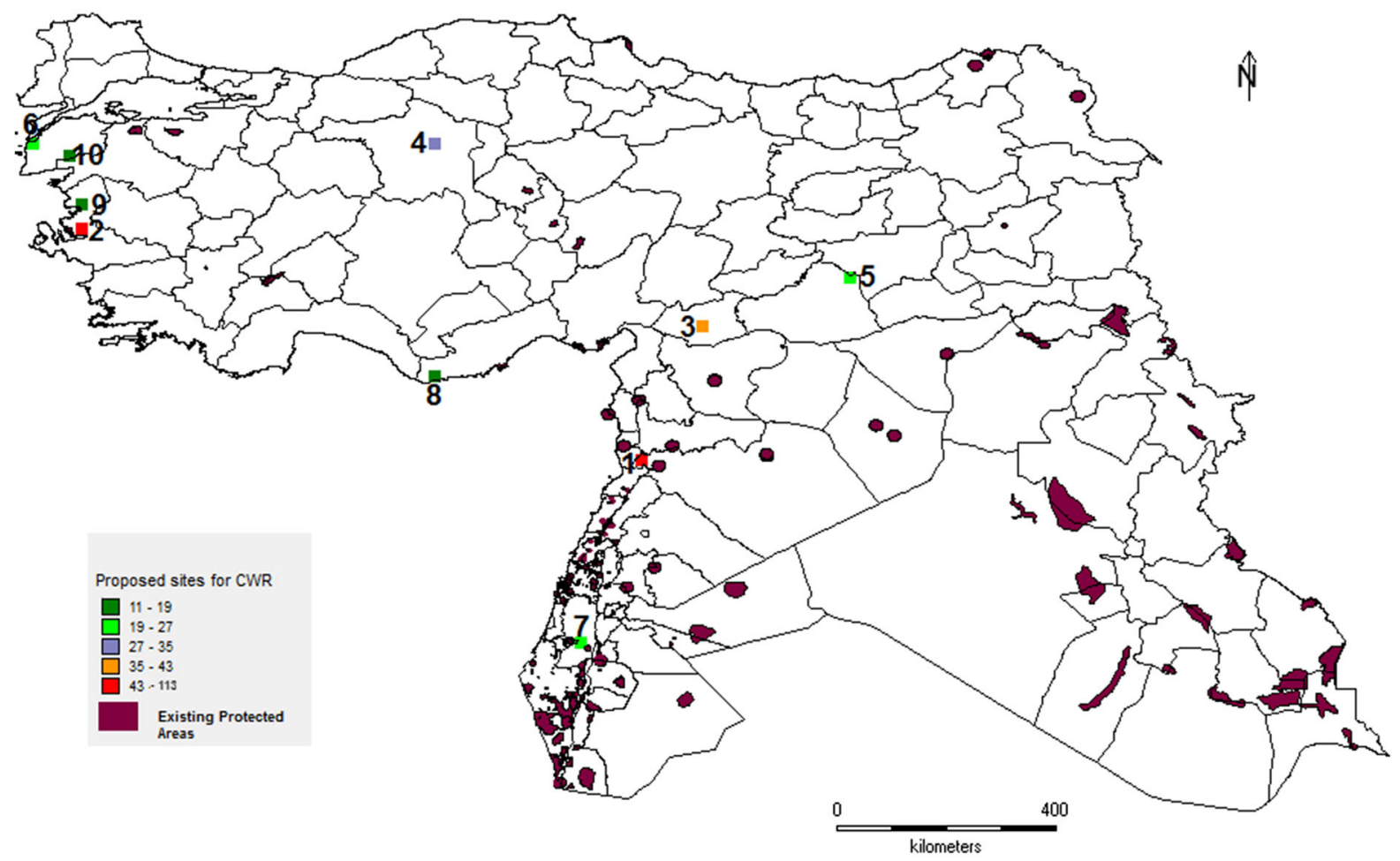

Fig. 3 Complementary analysis of 441 priority CWR and the existing protected areas in the Fertile Crescent using a cell size of $0.2^{\circ}$. All these ten sites cover all the 441 CWR taxa

CWR taxa to cover two-thirds of the $\mathrm{CWR}=\mathrm{S} 1+\mathrm{S} 2+\mathrm{S} 3+\mathrm{S} 4$

$\mathrm{S} 1$ number of CWR taxa at site 1

S2 number of CWR taxa at site 2

S3 number of CWR taxa at site 3.

S4 number of CWR taxa at site 4.

For the ex situ gap analysis, gaps in the ecogeographic representation of CWR priorities of the Fertile Crescent in gene banks were identified (Fig. 4, Supplementary Tables 1 and 2), after Ramirez-Villegas et al.'s (2010) methodology followed by Castaneda-Alvarez et al. (2016). MaxEnt version 3.4 was used to obtain species distribution models of the 441 taxa (Phillips et al. 2006). The 19 bioclimatic variables extracted from WorldClim (Fick and Hijmans 2017) and outlined in Supplementary Table 3 were used in the models.

A total of 10,000 random points were used as background records across the study area, and fivefold cross-validation $(\mathrm{k}=5)$ was implemented. Maximum training sensitivity and specificity thresholds were used to restrict the modelled potential distributions.
Only models that fulfilled the following validation criteria were considered to be stable and used in further analyses (Ramirez-Villegas et al. 2010):

- Fivefold average area under the test data ROC curve (ATAUC) above 0.7 .

- Standard deviation of ATAUC (STAUC) below 0.15 .

- Proportion of potential distribution area with a standard deviation above 0.15 (ASD15) and below $10 \%$.

For those taxa that lacked stable models, a 50-km round buffer was applied when only ten present points were available. To assess whether the species conserved ex situ were ecogeographically and adequately conserved, three scores were estimated: RamirézVillegas et al.'s (2010) Geographic Representativeness Score (GRS), Environmental Representativeness Score (ERS) and Sampling Representativeness Score (SRS). To prioritise each target taxon for the collection of ex situ conservation, all representativeness scores (i.e. SRS, GRS and ERS) were averaged with an 


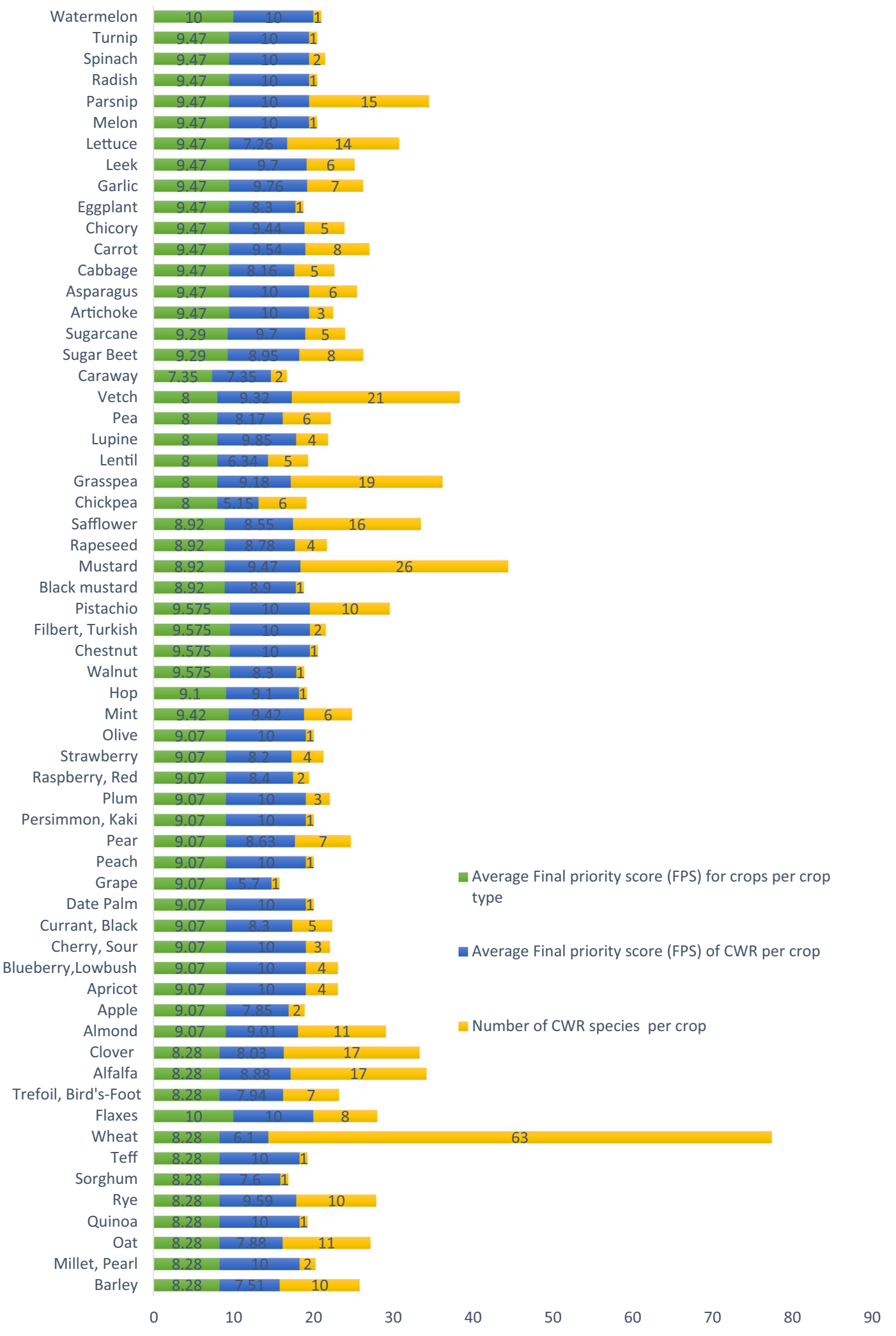


4Fig. 4 Mean priority score values for ex situ conservation of CWR in the Fertile Crescent

equal weighting to obtain the final prioritisation score (Ramiréz-Villegas et al. 2010).

Following Castaneda-Alvarez et al. (2016), if the Final Priority Score (FPS) is more than seven, the taxon is considered a high priority for ex situ conservation; if the score is between five and seven, the taxon is considered a medium priority; the taxon is considered a low priority for conservation if it is between 2.5 and 5 .

Another method to undertake gap analysis involves conducting the Ecogeographic Land Characterisation (ELC) analysis in CAPFITOGEN version 1.2 and applying the ELCmapas tool (Parra-Quijano et al. 2014). Geophysical and bioclimatic variables were standardised in Excel and tested for collinearity (Dormann et al. 2013) by running an $\mathrm{R}$ script (see the supplementary materials), which resulted in 11 variables comprising five geophysical variables and six bioclimatic variables (i.e. bio_15, bio_3, bio_5, bio_6, bio_8 and prec_6). The five geophysical and six bioclimatic variables were then run through a Principal Component Analysis (PCA) in SPSS, where variables were chosen based on the highest loadings $(>0.3)$. This resulted in four geophysical variables (i.e. slope, altitude, northness and eastness) and three bioclimatic variables (bio_8, bio_6 and bio _15).

MaxEnt version 3.4 was used to calculate CWR potential richness. The MaxEnt results were uploaded onto DIVA-GIS Version 7.5 (see Fig. 5 for DIVA-GIS results). The map in Fig. 6 resulted from overlaying the potential richness map with the current route richness diversity layer. The aim of Fig. 6 analysis was to find gaps for further collections.

List of experts who evaluated the gap analysis are presented in Supplementary Table 14.

In summary, this analysis aimed to find projected hotspots for future collection of high priority CWRs. Plant genetic materials from these projected hotspots can be used in ex situ conservation and gene banks.

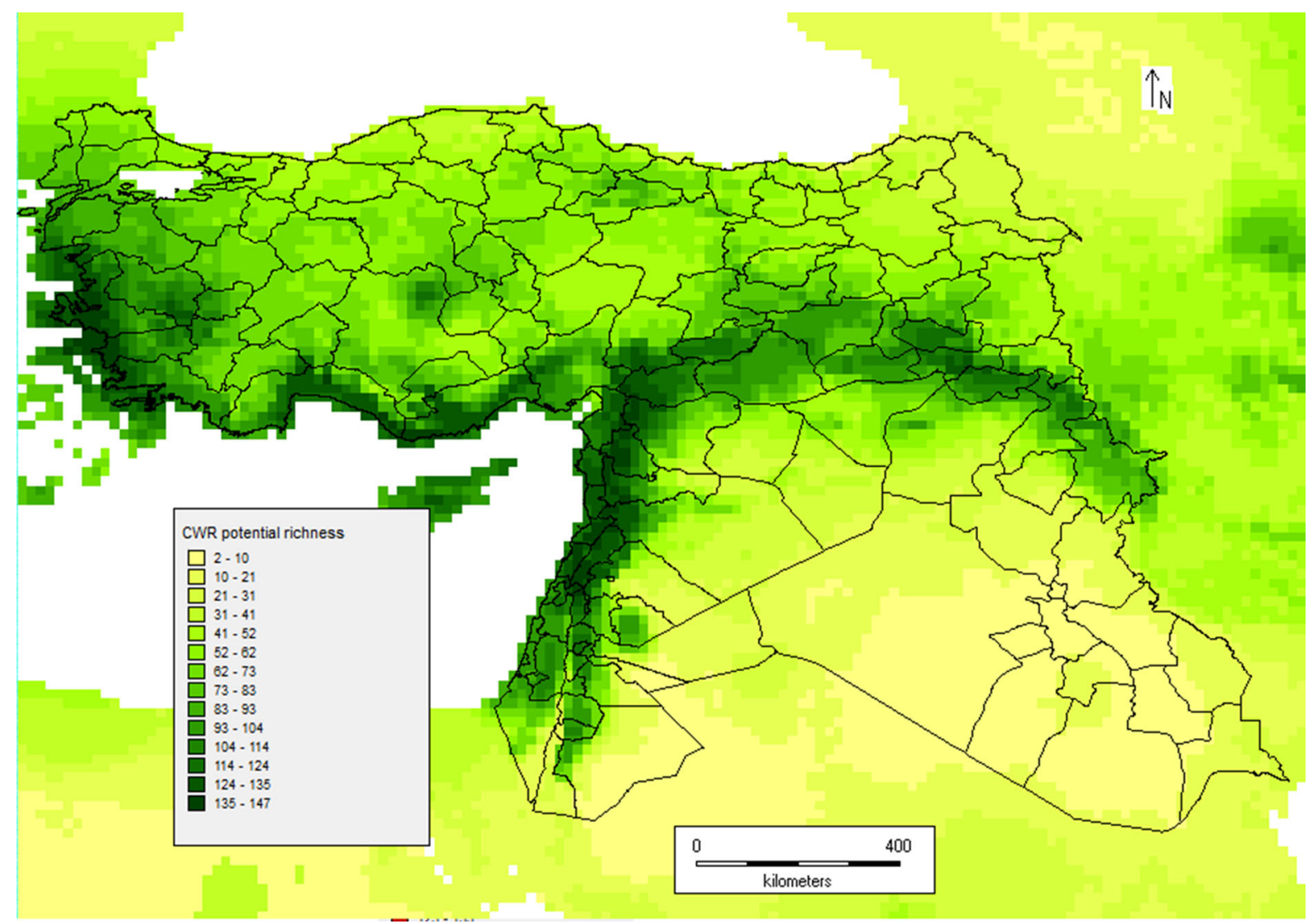

Fig. 5 CWR potential richness; the legend displays the number of CWR species with a grid cell of 5 -min degrees $\left(\sim 9 \mathrm{~km}^{2}\right)$ 


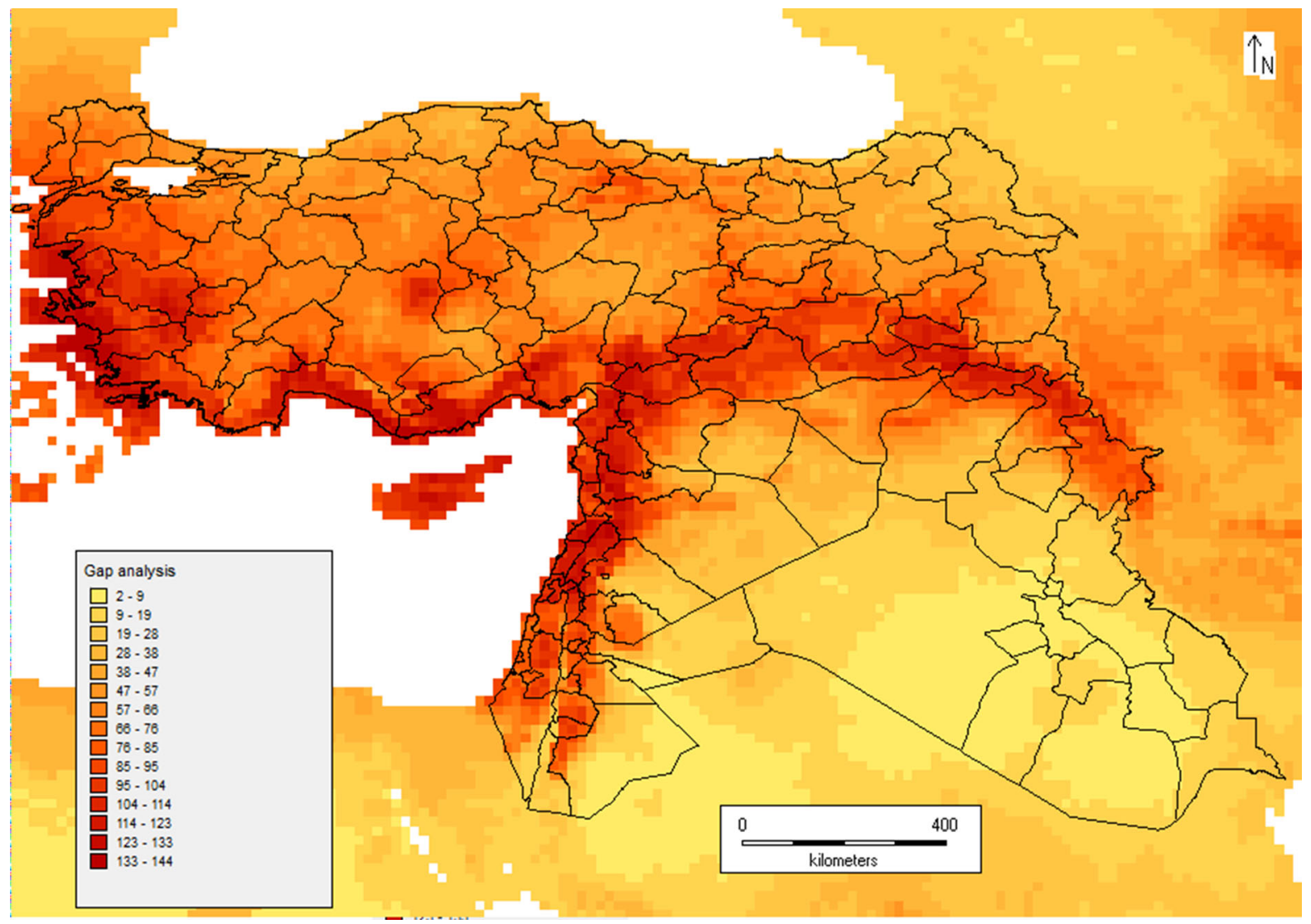

Fig. 6 CWR ex situ gap analysis of high priority CWR in the Fertile Crescent with a grid cell of 5-min degrees $\left(\sim 9 \mathrm{~km}^{2}\right)$

\section{Results}

The priority list of crop wild relatives in the Fertile Crescent consists of 441 CWR taxa (Supplementary Table 1). Passport data of these 441 CWR taxa were collated and are presented in Supplementary Table 2. A total of 23,878 presence points (latitudes and longitudes) representing the $441 \mathrm{CWR}$ priority list taxa in the Fertile Crescent are presented in Supplementary Table 3 and used in the subsequent analyses. Hordeum vulgare L. subsp. spontaneum (K. Koch) Thell, a wild relative of barley, has the largest number of presence points with 2190 occurrence records. Vavilovia formosa (Steven) Fed. was found to be the rarest with only one presence point. The associated crops of the 441 CWR taxa are summarised in Supplementary Table 4 and used in the following analyses.

Presence points for the 441 priority CWR taxa of the Fertile Crescent region are shown in Fig. 1, and the arc of the Fertile Crescent is visible in Fig. 2. Ten sites (Fig. 3 and Supplementary Table 5) are needed to conserve all 441 priority CWR taxa, and the number of taxa in each site is marked in Table 1. Ideally, when implementing in situ conservation of CWRs, genetic reserves should be located within the existing protected areas to limit the costs associated with the establishment of new conservation areas (Dulloo et al. 2008). However, a few of the 10 priority sites are located in or adjacent to the existing protected areas because of a lack of protected area coverage in the Middle East. However, site 7, Anata, is relatively close to Wadi el Qilt Nature Reserve in the Palestinian territories. The borders of these protected areas have been suggested to be extended to include the CWRs' locations.

CWR taxa to cover two-thirds of the CWR tax $\mathrm{a}=\mathrm{S} 1+\mathrm{S} 2+\mathrm{S} 3+\mathrm{S} 4=113+112+43+35$ $=303$ CWR taxa. The results show that the first four sites (Homs, Izmir, Gaziantep and Ankara) need to cover two-thirds of all taxa.

The ex situ gap analysis indicates that priority CWRs in the Fertile Crescent (Supplementary Table 6) are under-represented in gene banks. Of the 441 taxa, 
Table 1 Priority sites of in situ CWR conservation

\begin{tabular}{|c|c|c|c|c|c|c|c|}
\hline Site number & Country & Province & Locality & Latitude & Longitude & Number of CWR taxa & $\begin{array}{l}\text { Taxa not } \\
\text { occurring } \\
\text { at this site }\end{array}$ \\
\hline 1 & Syria & Homs & Tel Kalakh & 34.730611 & 36.133611 & 113 & 328 \\
\hline 2 & Turkey & Izmir & Menemen & 38.5604 & 27.0878 & 112 & 329 \\
\hline 3 & Turkey & Gaziantep & Burc Karakuyu & 36.9485 & 37.2360 & 43 & 398 \\
\hline 4 & Turkey & Ankara & Cankaya & 39.873040 & 32.806458 & 35 & 406 \\
\hline 5 & Turkey & Sanliurfa & Siverek & 37.7895 & 39.6609 & 27 & 414 \\
\hline 6 & Turkey & Canakkale & Kumkale Koyu & 39.9735 & 26.2328 & 27 & 414 \\
\hline 7 & Palestinian Terr & Jerusalem & Anata & 31.8183 & 35.2596 & 27 & 414 \\
\hline 8 & Turkey & Mersin & Anamur & 36.1668 & 32.8148 & 19 & 422 \\
\hline 9 & Turkey & Edremit & Doyran & 39.6730 & 26.7040 & 19 & 422 \\
\hline 10 & Turkey & Aziziye & Tebrizcik & 39.9485 & 41.0041 & $\begin{array}{l}19 \\
441 \text { (total CWR taxa) }\end{array}$ & 422 \\
\hline
\end{tabular}

134 (30\%) CWRs are totally absent from the current gene banks collections. Only 307 (70\%) CWRs are represented in gene banks (Supplementary Table 7), and, of these taxa, $252(57 \%)$ of them have less than 10 accessions in gene banks.

A total of 353 taxa were categorised as a high priority for collection and conservation; 23 taxa were categorised as a medium priority and 41 taxa as a low priority. However, 24 taxa were identified that did not require urgent collection (see Supplementary Table 7). A lack of geographical and ecological representation in gene banks leads to high FPS scores, with clear gaps in ex situ conservation of these taxa.

An examination of CWR taxa, sorted by their related crops, indicated that 57 crops $(93 \%)$ had been relegated to a high need for further gathering, with the gene pool of these crops requiring serious protection activities (see Fig. 4).

The analysis in Supplementary Table 8 demonstrates that the mean FPS values per related crop are 7.51 for barley, 7.6 for sorghum, 7.88 for oat, 8.17 for pea, 8.95 for sugar beet, 9.59 for rye and 9.63 for sugar cane. The mean FPS values for fruits are 10 for apricot, blueberry, cherry, date palm, peach, persimmon and plum. Four crops (7\%) of the crop gene pools had been assigned as a medium priority for further collection, and their FPS values are 6.34 for lentil, 6.1 for wheat, 5.7 for grape and 5.15 for chickpea. As can be seen in Supplementary Table 9, wild relatives of pulses, cereals, oil crops, fruits, industrial crops, sugar crops, herbs, vegetables, nuts and spices were assessed as being a high priority for collection. The mean FPS values for crop types are 8.735 for spices, 8 for pulses, 8.28 for cereals, 8.92 for oil crops, 9.07 for fruits, 9.1 for industrial crops, 9.29 for sugar crops, 9.42 for herbs, 9.47 for vegetables and 9.575 for nuts.

Of all the examined CWRs related to 61 crops, no crop gene pool can be considered well represented in gene banks. Wild relatives of wheat have been used as a source of genetic materials for crop improvement and collected in gene banks, and they are categorised as a medium priority for collection. Medium priority gene pools, such as chickpea and lentil, have fewer CWRs than wheat. As Supplementary Table 10 in Fig. 7 shows, the FPS across the CWR priority list in the Fertile Crescent has been categorised according to the gene pool and crop. Although some crops have been assessed as being a low priority for conservation, some taxa related to these crops are a high priority for ex situ conservation. Certain CWRs related to wheat were evaluated as being under-represented in gene banks, such as Aegilops comosa Sm., Thinopyrum pycnanthum (Godr.) Barkworth and Agropyron cristatum (L.) Gaertn. Only the high priority category for further collection are presented in Supplementary Table 11.

The gaps in ex situ conservation refer to areas where taxa potentially occur, with accessions for ex situ conservation not collected and, thus, missing in gene banks (Scheldeman et al. 2007).

As Fig. 5 shows, the highest concentration of projected CWR diversity can be found in the west of Syria in an area from north Lattakia to south Tartus, alongside the coastal area of Turkey from the city of Bandirma in the Sea of Marmara to the town of 
Yayladagı in Hatay Province in southern Turkey, across the border between Turkey and Syria and north-east of Iraq, across the mountains in Lebanon and the seashore, west of Jordan alongside the border between Israel and Jordan and alongside the coastal area of Israel. Some countries, such as Iraq, have a few presence points. However, the analysis revealed that the north of Iraq contains high potential CWR taxa richness.

Ex situ conservation gaps were identified across the Fertile Crescent regions in Fig. 6, with the most important gaps being in the west and south of Turkey across the Mediterranean seashore, north of Lebanon, west of Syria in Lattakia and Tartus Governorate, across the border between Turkey and Syria and north of Iraq. In such sites, between 133 and 144 CWR taxa are expected to exist in a single grid square.

Projected hotspots for future seed collection of priority CWR in the Fertile Crescent are presented. The map corresponds to gaps in ex situ conservation, as these taxa are not conserved at all. The legend displays the number of CWR taxa per cell. CWR taxa ranging from 133 to 144 are expected to exist in the extremely dark red cells. Between two and nine CWR taxa are expected to exist in the pale-yellow areas. The map is the result of overlaying the potential richness map with the current route richness diversity layer to identify gaps for further collections.

The analysis in Fig. 6 only considers high priority CWR taxa. The deep red colour means that collection is required in these areas and that no ex situ collection has been undertaken before for CWR in these sites, although these sites are suitable for CWR high priorities.

\section{Discussion}

One of the purposes of this study was to create a regional database of occurrence records for the priority CWRs in the Fertile Crescent. To this end, 23,878 records were collated. The methods used to identify the richest hotspots for CWR diversity in the Fertile Crescent are in line with previously published methods (e.g. Fielder et al. 2015; Phillips et al. 2016).

The findings of this study can help policymakers set out effective protocols to conserve CWRs. CWRs play an essential role in current and future food security strategies. They have been used as a source of diversification for domesticated crops and have contributed to improved yields by introducing genes that strengthen insects and plants against diseases and increase tolerance for salinity stress, drought and extreme weather conditions. There is a wide diversity of CWRs throughout the Fertile Crescent, and this study recommends candidate genetic reserves, intended for active CWR conservation, as a keystone for implementing a regional conservation strategy for such important genetic resources.

This paper strongly recommends the implementation of the proposed CWR genetic reserves. The findings of this study are significant, mainly because the results from the analysis of occurrence data are critical to the conservation of CWRs. Although several publications have discussed some of the biodiversity hotspots in the region, most of them have chosen to focus on a particular genus. Shehadeh (2011), for example, identifies a hotspot in the Talkalakh area of Syria for Lathyrus taxa diversity and another hotspot in the Osmaniye province of Turkey for Lathyrostylis.

The richest hotspots for CWR diversity have been found in the north-west of Syria, north of Lebanon, and west and east of Turkey, including the Ankara region. Protected spots of CWR in the Fertile Crescent have also been recommended. Site 1 , Tel Kalakh, is relatively close to Quttina Lake's protected area near Homs in Syria, and site 2, Izmir, is relatively close to Gediz Delta's protected area, a Ramsar site in Turkey. However, both sites appear to be unsuitable habitats for CWR in situ conservation. Therefore, active in situ CWR conservation in the Fertile Crescent will require either the establishment of new protected areas or the promotion of active in situ conservation in less formally managed sites.

The protected spots of CWR are vital to the conservation of our genetic resources to help our planet overcome climate change and other threats to agricultural biodiversity and food security. This study provides the minimum biodiversity hotspots needed.

In the future, it is necessary to combine the taxa richness with potential richness for adaptive traits, which can increase the number of recommended protected areas. A trait can be defined as adaptive if it is suitable to survive in new natural environmental conditions (Ackerly et al. 2000). In other words, only CWR taxa that have adaptive traits for climate change and other environmental stress, are resistant to pests and diseases and have the ability to increase yield in the Fertile Crescent will be selected to identify genetic reserves for them.

The results indicate that the representation gaps in gene banks need to be filled, especially for high 
priority under-represented taxa related to barley, sorghum, oat, pea, sugar, beet, rye and sugarcane. To study the impact of climate change on CWR taxa, further studies are needed.

After carefully examining the representation of priority CWRs in global gene banks, it can be concluded that there is a lack of representation in gene banks and that efforts are urgently required to conserve them ex situ. To fill the conservation gaps, seeds need to be collected from areas that are rich in CWRs and have been outlined in the ex situ gap analysis map through site visits. National and regional gene banks, with the aid of universities, local communities and governmental departments, can be used to accomplish the collection mission. Duplicates of the seed samples should then be sent to international gene banks, such as the Svalbard Seed Vault.

Collected CWR seeds should also be crossed with domesticated crops to transfer the desired genes, based on the gene pool assessment. More advanced techniques, such as in vitro gene transfer, can be used for CWR taxa which are difficult to cross using the natural breeding methods.

The gap analysis method using MaxEnt version 3.4.1 and DIVA-GIS is an effective calculation method to detect geographical areas that are rich in CWRs or under-represented taxa. The use of the number of germplasm accessions in the assessment is an effective method in the gap analysis because if the number is low, the priority for collection increases. The FPS is used to effectively identify priorities that not only rely on the number of germplasm accessions but also on the number of samples and other factors.

\section{Conclusion}

A regional database of occurrence records was created for CWRs in the Fertile Crescent. The richest hotspots for CWR diversity were identified in the Fertile Crescent, located in Syria near the Lebanese border and the Syrian Coastal Mountain Range in the northwest of Syria, north-west of Jordan and several places in Turkey. Ten virtual CWR genetic reserves were recommended for the Fertile Crescent. Both the data and methodology applied can be used in setting strategies to conserve CWR plant genetic resources and help the Fertile Crescent meet its targets in conserving CWR diversity; they can also be used to ensure that CWR genetic resources are preserved to prevent and tackle global food insecurity.

The ex situ gap examination showed that $30 \%$ of CWR taxa have no representation in gene banks and that only $70 \%$ of the examined CWR taxa are represented. Significant gaps in ex situ conservation are prevalent in the west and south of Turkey across the Mediterranean seashore, north of Lebanon and west of Syria (in Lattakia and Tartus Governorate), across the border between Turkey and Syria and northern Iraq.

Acknowledgements This paper resulted from a collaboration between the School of Biosciences, University of Birmingham, UK and the Genetic Resources Section, the International Centre for Agricultural Research, Dry Areas (ICARDA).

\section{Compliance with ethical standards}

Conflict of interest The authors declare that they have no conflict of interest.

Open Access This article is licensed under a Creative Commons Attribution 4.0 International License, which permits use, sharing, adaptation, distribution and reproduction in any medium or format, as long as you give appropriate credit to the original author(s) and the source, provide a link to the Creative Commons licence, and indicate if changes were made. The images or other third party material in this article are included in the article's Creative Commons licence, unless indicated otherwise in a credit line to the material. If material is not included in the article's Creative Commons licence and your intended use is not permitted by statutory regulation or exceeds the permitted use, you will need to obtain permission directly from the copyright holder. To view a copy of this licence, visit http://creativecommons.org/licenses/by/4.0/.

\section{Appendix}

\section{ELC map}

The ELCmapas tool (CAPFITOGEN version 1.2) was used to create the ecogeographic map (Parra-Quijano et al. 2014). First, a subset of variables was selected for this analysis (see Supplementary Table 15). The environmental data was combined with the presence point data for the priority taxa in the Fertile Crescent. The ELCmapas used the 23,878 presence points which represent the $441 \mathrm{CWR}$ priority list for the Fertile Crescent. Figures 7, 8, 9, 10, 11, 12 and 13 display the ELC map of the Fertile Crescent using the variables 


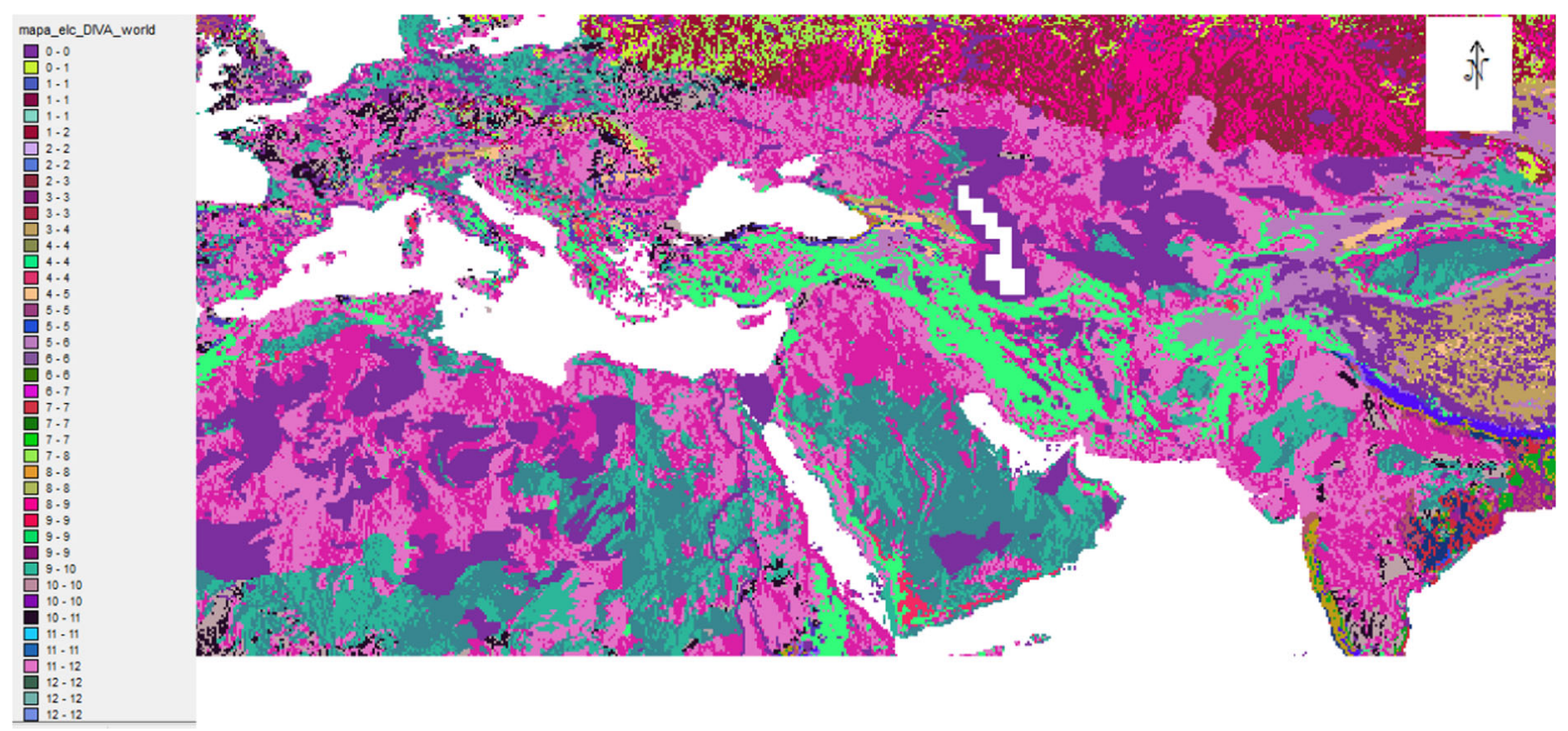

Fig. 7 An ELC map of the Fertile Crescent using the environmental variables with elbow method (CAPFITOGEN) (cell size $10 \times 10 \mathrm{~km})$
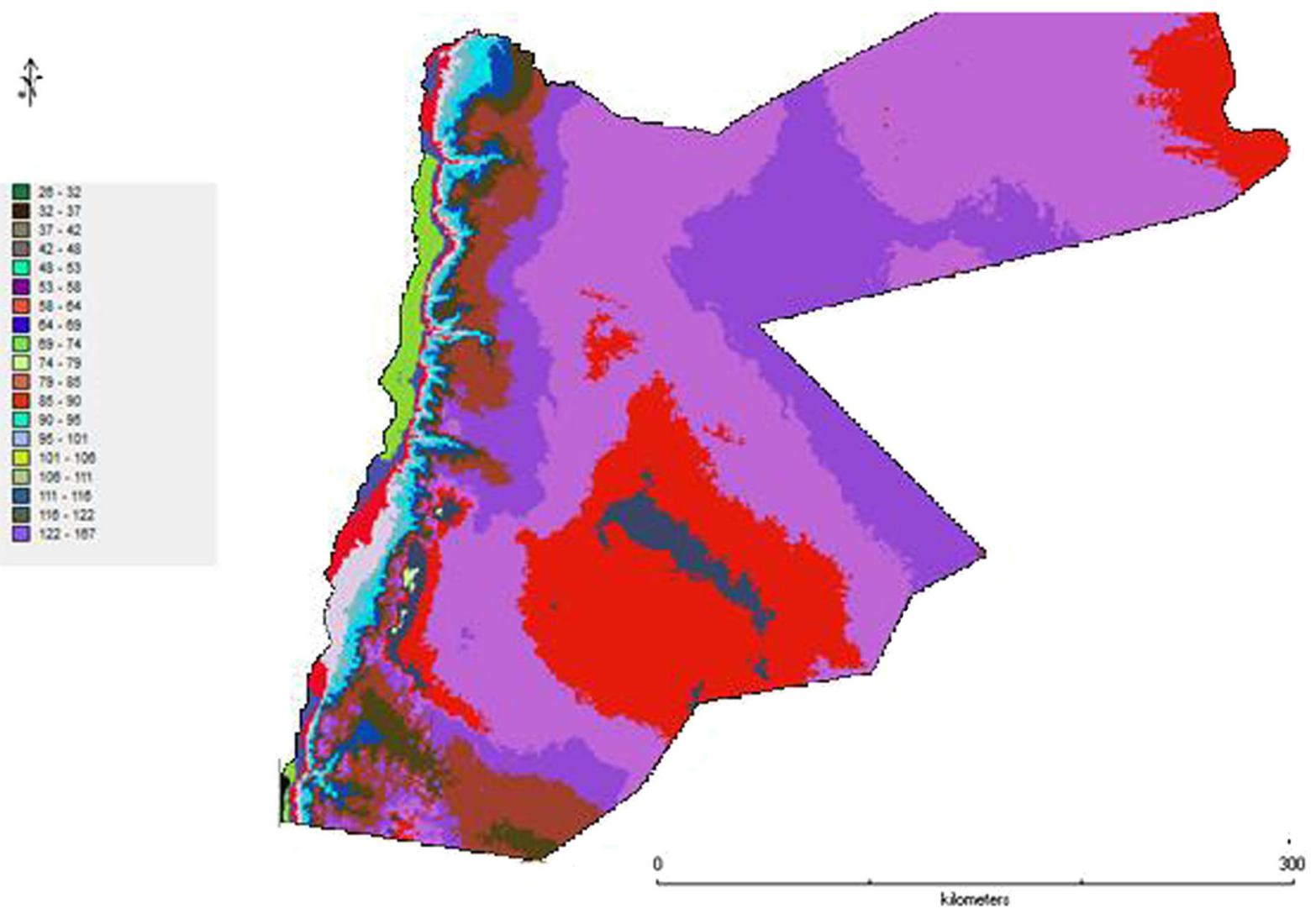

Fig. 8 ELC map of Jordan using the environmental variables with the elbow method (CAPFITOGEN) $($ cell size $1 \times 1 \mathrm{~km})$ 


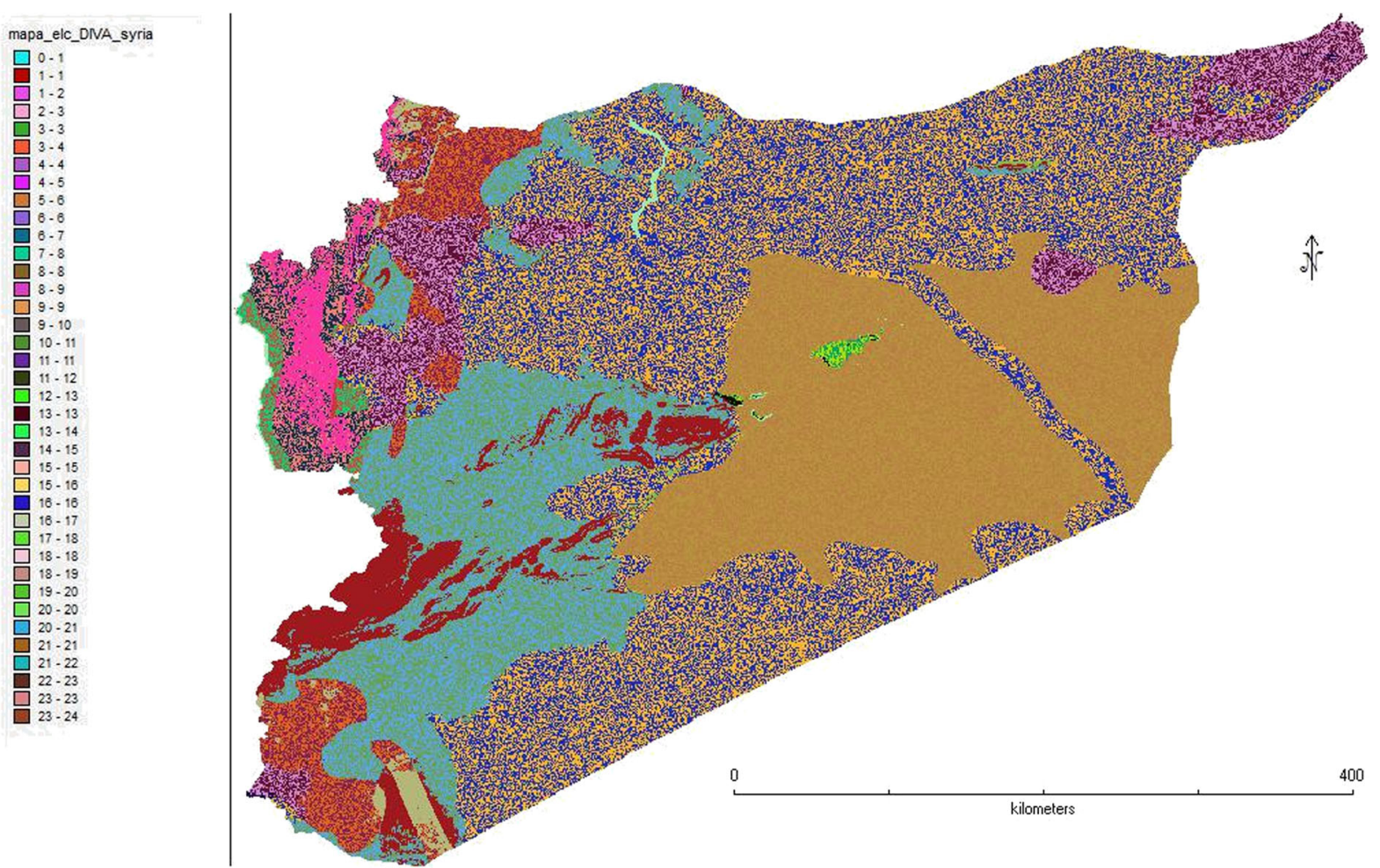

Fig. 9 An ELC map of Syria using the environmental variables with the elbow method (CAPFITOGEN) $($ cell size $1 \times 1 \mathrm{~km})$ 


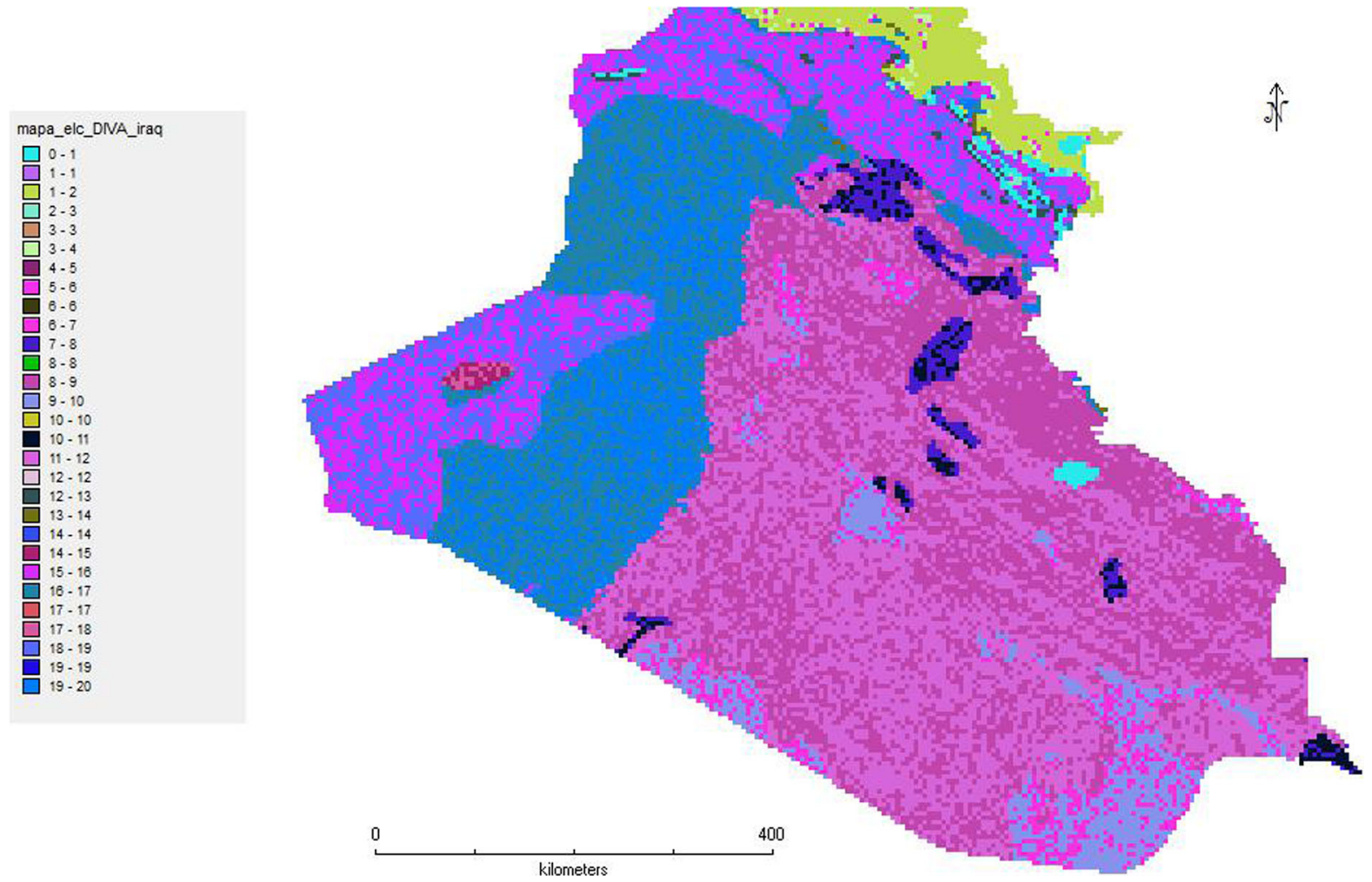

Fig. 10 ELC map of Iraq using the environmental variables with the elbow method (CAPFITOGEN) (cell size $5 \times 5 \mathrm{~km}$ )
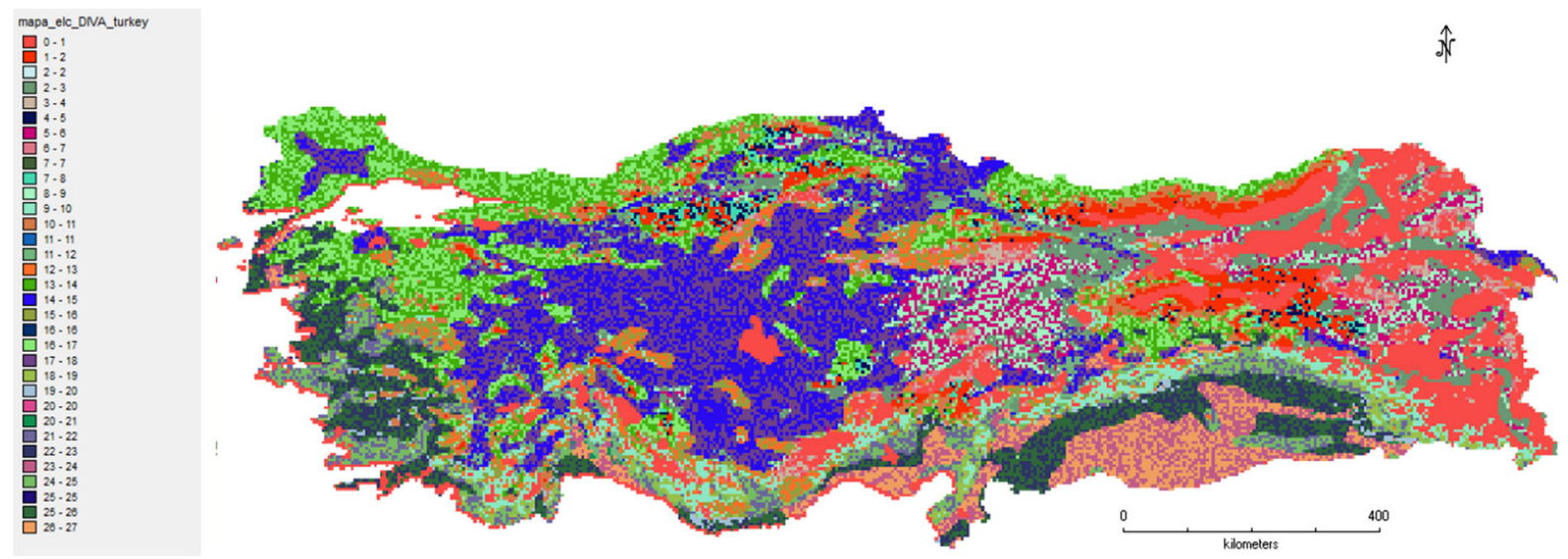

Fig. 11 An ELC map of Turkey using the environmental variables with the elbow method (CAPFITOGEN) $($ cell size $5 \times 5 \mathrm{~km})$ 
Fig. 12 An ELC map of Israel using the environmental variables with the elbow method (CAPFITOGEN) (cell size $5 \times 5 \mathrm{~km}$ )

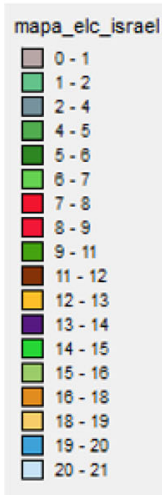

0

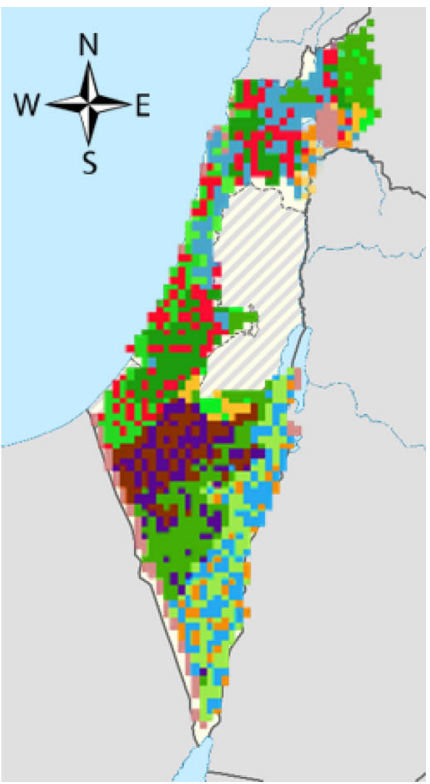

Fig. 13 An ELC map of Lebanon using the environmental variables with the elbow method (CAPFITOGEN) (cell size $5 \times 5 \mathrm{~km}$ )

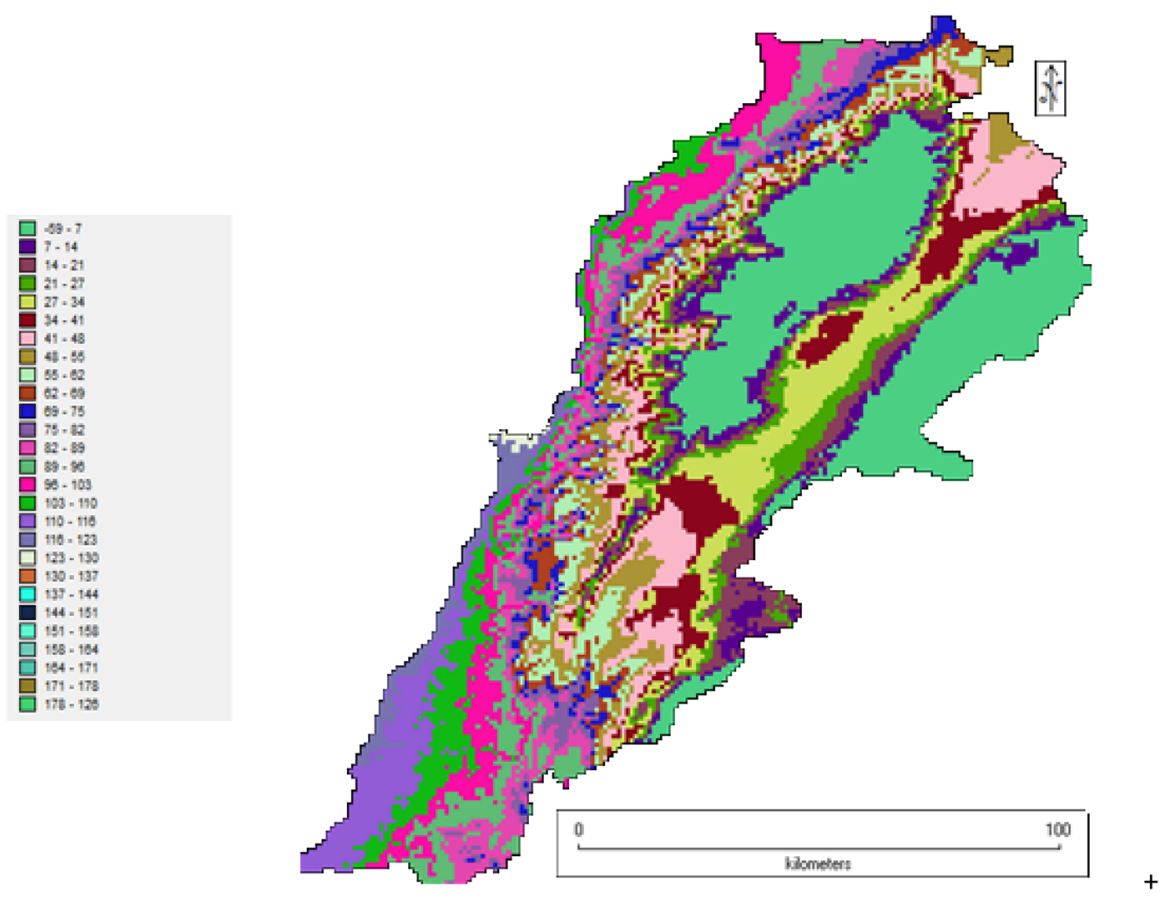


listed in Supplementary Table 3 with elbow method $($ CAPFITOGEN) $($ cell size $10 \times 10 \mathrm{~km})$.

\section{References}

Ackerly D, Dudley S, Sultan S, Schmitt J, Coleman J, Linder C, Sandquist D, Geber M, Evans A, Dawson T, Lechowicz M (2000) The evolution of plant ecophysiological traits: recent advances and future directions. Bioscience 50(11):979-995

Araus JL, Slafer GA, Royo C, Serret MD (2008) Breeding for yield potential and stress adaptation in cereals. Crit Rev Plant Sci 27:377-412

Asseng S, Ewert F, Martre P et al (2015) Rising temperatures reduce global wheat production. Nat Clim Change 5:143-147

Breasted JH (1916) Ancient times, a history of the early world: an introduction to the study of ancient history and the career of early man. Ginn and Co, Boston

Castaneda-Alvarez NP, Khoury CK, Achicanoy HA, Bernau V, Dempewolf H, Eastwood RJ, Guarino L, Harker RH, Jarvis A, Maxted N, Mueller JV, Ramirez-Villegas J, Sosa CC, Struik PC, Vincent H, Toll J (2016) Global conservation priorities for crop wild relatives. Nat Plants 2:16022. https://doi.org/10.1038/nplants.2016.22

CBD (1992) Convention on biological diversity. http://www. cbd.int/doc/legal/cbd-en.pdf. Accessed Sept 2020

Clay AT (1924) The so-called Fertile Crescent and desert bay. Am Orient Soc 44:186-201

Derneg D (2010) Ecosystem profile: Mediterranean basin biodiversity hotspot. CEPF-critical ecosystem partnership fund. https://www.cepf.net/Documents/Mediterranean_ EP_FINAL.pdf. Accessed Sept 2019

Dormann CF, Elith J, Bacher S, Buchmann C, Carl G, Carre G, Marquez JRG, Gru-ber B, Lafourcade B, Leitao PJ, Münkemüller T, McClean C, Osborne PE, Reinek-ing B, Schroder B, Skidmore AK, Zurell D, Lautenbach S (2013) Collinearity: a review of methods to deal with it and a simulation study evaluating their performance. Ecography 36(1):27-46. https://doi.org/10.1111/j.1600-0587.2012. 07348.x

Dulloo ME, Labokas J, Iriondo JM, Maxted N, Lane A, Laguna E, Kell SP (2008) Genetic reserve location and design. In: Iriondo J, Maxted N, Dulloo ME (eds) Conserving plant genetic diversity in protected areas. CABI Publishing, Wallingford, pp 23-64

El-Beltagy A (2006) Central and West Asia and North Africa: challenges and opportunities. ICARDA, Aleppo

FAO (2009) How to Feed the World in 2050 Executive Summary, available at https://www.fao.org/fileadmin/ templates/wsfs/docs/expert_paper/How_to_Feed_the_ World_in_2050.pdf as Accessed on September 2017

FAO (2011) The state of the world's land and water resources for food and agriculture: managing systems at risk. Food and Agriculture Organization of the United Nations Rome and Earthscan, London
FAO (2015) The second report on the State of The World's Plant Genetic Resources for Food and Agriculture. Food and Agriculture Organisation of the United Nations, Rome, Italy. www.fao.org/docrep/013/i1500e/i1500e00.htm Accessed 12 Jan 17

Fick SE, Hijmans RJ (2017) Worldclim 2: New 1-km spatial resolution climate surfaces for global land areas. Int $\mathrm{J}$ Climatol 37:4302

Fielder H, Brotherton P, Hosking J, Hopkins JJ, Ford-Lloyd B, Maxted N (2015) Enhancing the conservation of crop wild relatives in England. PLoS ONE 10(6):e0130804. https:// doi.org/10.1371/journal.pone.0130804

GEOLocate (2017) GEOLocate software https://www.museum. tulane.edu/geolocate/as. Accessed on January 2017

Godfray HCJ, Beddington JR, Crute I, Haddad L, Lawrence D, Muir JF, Pretty J, Robinson S, Thomas SM, Toulmin C (2010) Food security: the challenge of feeding 9 billion people. Science 327:812-818

Harlan JR (1951) Anatomy of gene centers. Am Nat 85:97-103

Harlan JR, Zohary D (1966) Distribution of wild wheats and barleys. Science 153:1074-1050

Hawkes JG (1983) The diversity of crop plants. Harvard University Press, Cambridge

Jarvis A, Lane A, Hijmans RJ (2008) The effect of climate change on crop wild relatives. Agric Ecosyst Environ 126(1-2):13-23

Kell SP, Maxted N, Bilz M (2012) European crop wild relative threat assessment: knowledge gained and lessons learnt. In: Maxted N, Dulloo ME, Ford-Lloyd BV, Frese L, Iriondo JM, Pinheiro de Carvalho MAA (eds) Agrobiodiversity conservation: securing the diversity of crop wild relatives and landraces. $\mathrm{CAB}$ International, Wallingford, pp 218-242

Kelley C, Mohtadi S, Cane M, Seager R, Kushnir Y (2015) Climate change in the Fertile Crescent and implications of the recent Syrian drought. PNAS 112(11):3241-3246. https://doi.org/10.1073/pnas.1421533112

Magos Brehm J, Kell S, Thormann I, Gaisberger H, Dulloo E, Maxted N (2017) Interactive toolkit for crop wild relative conservation planning version 1.0. University of Birmingham, Birmingham and Bioversity International, Rome. https://www.cropwildrelatives.org/conservation-toolkit/. Accessed Sept 2019

Maxted N, Ford-Lloyd BV, Jury S, Kell S, Scholten M (2006) Towards a definition of a crop wild relative. Biodivers Conserv 15(8):2673. https://doi.org/10.1007/s10531351005-5409-6

Maxted N, Hawkes JG, Ford-Lloyd BV, Williams JT (1997) A Practical model for in situ genetic conservation. In: Maxted N, Ford-Lloyd BV, Hawkes JG (eds) Plant genetic conservation: the in situ approach. Chapman \& Hall, London, pp 545-592

Maxted N, Kell SP, Ford-Lloyd BV, Dulloo ME, Toledo A (2012) Toward the systematic conservation of global crop wild relative diversity. Crop Sci 52(2):774-785

Maxted N, Anikster Y, Gustaffson M, Iriondo J, Hjalmarsson I, Rode J, Samaras S, Wingender R. with Laliberte B, Maggioni L, Turok J (2000) Wild Species Conservation in Genetic Reserves Task Force. Work-plan and Recommendations. In: Laliberté B, Maggioni L, Maxted N, Negri $\mathrm{V}$ (eds) Report of a joint meeting of a Task Force on Wild 
Species Conservation in Genetic Reserves and a Task Force on On-farm Conservation and Management, 18-20 May 2000, Isola Polvese, Italy. International Plant Genetic Resources Institute, Rome, pp 23-25

Maxted N, Magos Brehm J, Kell S (2013) Resource book for preparation of national conservation plans for crop wild relatives and landraces. http://www.fao.org/agriculture/ crops/thematic-sitemap/theme/seeds-pgr/resource-book/ en/. Accessed November 2018

Morrell PL, Clegg MT (2007) Genetic evidence for a second domestication of barley (Hordeum vulgare) east of the Fertile Crescent. Proc Natl Acad Sci 104(9):3289-3294

Myers N (1990) The biodiversity challenge: expanded hot-spots analysis. Environmentalist 10:243-256

Parra-Quijano M, Torres-Lamas E, Iriondo-Alegría J M, Lopez F (2014) CAPFITOGEN Tools-program to strengthen capabilities in National Plant Genetic Resources Programs in Latin America. Versión 1.2, FAO, Rome

Phillips SJ, Anderson RP, Schapire RE (2006) Maximum entropy modeling of species geographic distributions. Ecol Model 190:231-259

Phillips J, Asdal §̊, Magos Brehm J, Rasmussen M, Maxted N (2016) In situ and ex situ diversity analysis of priority crop wild relatives in Norway. Divers Distrib 22:1112-1126

Protected Planet (2018) Protected areas. https://www. protectedplanet.net. Accessed November 2018

Ramirez-Villegas J, Khoury C, Jarvis A, Debouck DG, Guarino L (2010) A gap analysis methodology for collecting crop genepools: a case study with Phaseolus beans. PLoS ONE 5(10):e13497. https://doi.org/10.1371/journal.pone. 0013497

Rebelo AG (1994) Iterative selection procedures: centres of endemism and optimal placement of reserves. In: Huntley BJ (ed) Botanical diversity in Southern Africa. National Botanical Institute, Pretoria, pp 231-257

Scheldeman X, van Zonneveld M (2010) Training manual on spatial analysis of plant diversity and distribution. In: Bioversity International, Rome, p 179. https://www. bioversityinternational.org/training/training_materials/ gis_manual.html. Accessed Sept 2019

Scott JM, Csuti B, Smith K, Estes JE, Caicco S (1991) Gap analysis of species richness and vegetation cover: an integrated biodiversity conservation strategy. In: Kohm K (ed) Balancing on the brink of extinction. Island Press, Washington, pp 282-297
Shehadeh A (2011) Ecogeographic, genetic and taxonomic studies of the genus Lathyrus L. Ph.D. thesis, University of Birmingham

Snir A, Nadel D, Groman-Yaroslavski I, Melamed Y, Sternberg M et al (2015) The origin of cultivation and proto-weeds, long before neolithic farming. PLoS ONE 10(7):e0131422. https://doi.org/10.1371/journal.pone.0131422

Tanksley SD, McCouch SR (1997) Seed banks and molecular maps: unlocking genetic potential from the wild. Science 277:1063-1066

Tilman D, Clark M (2014) Global diets link environmental sustainability and human health. Nature 515:518-522

Trigo RM, Gouveia CM, Barriopedro D (2010) The intense 2007-2009 drought in the Fertile Crescent: impacts and associated atmospheric circulation. Agric Meteorol 150(9):1245-1257

UN (United Nations, Department of Economic and Social Affairs, Population Division) (2017) World population prospects: the 2017 revision, key findings and advance tables. Working paper no. ESA/P/WP/248

Vavilov NI (1926) The centers of origin of cultivated plants. Appl Bot Plant Breed 16(2):248

Vincent H, Wiersema J, Kell SP, Dobbie S, Fielder H, Castañeda-Álvarez NP, Guarino L, Eastwood R, León B, Maxted $\mathrm{N}$ (2013) A prioritised crop wild relative inventory as a first step to help underpin global food security. Biol Conserv 167:1-15

Zair W, Maxted N, Amri A (2017) Setting conservation priorities for crop wild relatives in the Fertile Crescent. Genet Resour Crop Evol 65:855-863. https://doi.org/10.1007/ s10722-017-0576-30

Zhang P, Zhang J, Chen M (2017) Economic impacts of climate change on agriculture: the importance of additional climatic variables other than temperature and precipitation. J Environ Econ Manag 83(2017):8-31

Zhukovsky PM (1950) Cultivated plants and their wild relatives. P.S. Hudson, 1962. (trans.). CAB. Farnham Royal

Zohary D (1969) The progenitors of wheat and barley in relation to domestication and agricultural dispersal in the Old World. In: Ucko PJ, Dimbleby GW (eds) The domestication and exploitation of plants and animals. Duckworth, London, pp 47-66

Publisher's Note Springer Nature remains neutral with regard to jurisdictional claims in published maps and institutional affiliations. 